\title{
São José de Grajaú: Primeira Prelazia da Diocese do Maranhão São José de Grajaú: First Prelature of the Diocese of Maranhão
}

\author{
Telma Bonifácio dos Santos Reinaldo ${ }^{1 *}$, Rafael de Jesus Pinheiro Privado ${ }^{1}$
}

\section{RESUMO}

Analisamos a criação da Prelazia de Grajaú com objetivo assistencial aos fiéis que habitavam a localidade no século XIX e a catequese dos índios através de desobrigas, assistência paroquial e missões influenciadas pelos missionários Frei Afonso de Castel di Lecco, no Mearim; Frei Davi Dezenzano, na zona de Turiaçu; Frei Samuel de Seregno, no Itapecuru; Frei Mansueto de Peveranza, Frei João Pedro de S. S. João e Frei Reinaldo de Paulo, nos limites do Maranhão e Piauí.Tais missões ambulantes pregadas no Maranhão e no Piauí, entre os anos de 1894 a 1896, segundo relatos dos missionários, foram catequizados 250.000 fiéis, feitas 80.000 crismas, 150.000 comunhões, milhares de matrimônios legitimados, vinte e quatro capelas construídas, oitenta e dois cruzeiros levantados e a construção de quarenta e quatro cemitérios, com vista ao alcance do projeto evangelizador do Frei Olearo. Procuramos através da leitura de bulas papais, bibliografia especializada na área e cartas trocadas entre os missionários envolvidos, entender e relatar a missão evangelizadora que deu origem a Diocese de Grajaú no município do mesmo nome.

Palavras-chave: Missão Evangelizadora; Catequese dos Indios; Prelazia de São José de Grajaú

\begin{abstract}
We analyze the creation of the Prelature of Grajaú with the objective of assisting the faithful who inhabited the locality in the 19th century and the catechesis of the Indians through releases, parish assistance and missions influenced by the missionaries Friar Afonso de Castel di Lecco, in Mearim; Friar Davi Dezenzano, in the Turiaçu area; Friar Samuel de Seregno, in Itapecuru; Frei Mansueto de Peveranza, Frei João Pedro de SS João and Frei Reinaldo de Paulo, on the limits of Maranhão and Piauí. faithful, 80,000 confirmations were made, 150,000 communions, thousands of legitimized marriages, twenty-four chapels built, eighty-two cruises raised and the construction of forty-four cemeteries, with a view to achieving the evangelizing project of Friar Olearo. Through the reading of papal bulls, specialized bibliography in the area and letters exchanged between the missionaries involved, we sought to understand and report the evangelizing mission that gave rise to the Diocese of Grajaú in the municipality of the same name.
\end{abstract}

Keywords: Evangelizing Mission; Catechesis of the Indians; Prelature of San José de Grajaú.

\footnotetext{
${ }^{1}$ UFMA.

*E-mail: telma.bonifacio@ufma.br; rafael.pinheiro@discente.ufma.br
} 


\section{INTRODUÇÃO}

Procuramos situar a atividade religiosa iniciada por Frei Carlos de São Martino Olearo ao Maranhão, com vista a criação da Prelazia de Grajaú. Frei Olearo como era conhecido, foi um religioso dotado de zelo incansável, ao fundar a missão de São José de Grajaú, que teria um duplo objetivo: a colaboração com o clero diocesano para uma assistência mais adequada aos fiéis e a catequese dos índios. Residindo em São Luís, enviava os seus missionários através da vastíssima Diocese maranhense, para fazerem desobrigas, assistência paroquial e missões ambulantes, que não deixavam de produzir bons resultados.

Logo nos primeiros anos toda a Diocese foi percorrida e sacudida pelas palavras dos missionários Frei Afonso de Castel di Lecco, no Mearim; Frei Davi Dezenzano, na zona de Turiaçu; Frei Samuel de Seregno, no Itapecuru; Frei Mansueto de Peveranza, Frei João Pedro de S. S. João e Frei Reinaldo de Paulo, nos limites do Maranhão e Piauí, alcançando coeficientes de pregações, confissões e comunhões verdadeiramente impressionantes. Tais missões ambulantes pregadas no Maranhão e no Piauí, entre os anos de 1894 a 1896, ultrapassaram a casa de centenas de milhares de desobrigas, confissões e comunhões com a adesão de 250.000 fiéis, 80.000 crismas, 150.000 comunhões, milhares de matrimônios legitimados, vinte e quatro capelas construídas, oitenta e dois cruzeiros levantados e a construção de cerca de quarenta e quatro cemitérios; além dos quilômetros percorridos a cavalo pelos missionários ou nas embarcações fluviais com vista ao alcance do projeto evangelizador do Frei Olearo.

É nesse contexto que nos acercamos para conhecer essa trajetória missionaria e seus resultados no interior do estado do Maranhão. Para tanto procuramos nos fundamentar nas bulas papais, nos escritos de autores maranhenses que se debruçam sobre essa temática. e nas correspondências trocadas entre os missionários e a Santa Sé.

\section{A INDICAÇÃO DOS BISPOS PARA ATUAREM NO MARANHÃO}

Um dos bispos mais ilustres da Diocese de São Luís do Maranhão foi Dom Antônio Cândido de Alvarenga (1877-1898) nascido em São Paulo no dia 22 de abril de 1836 morreu em 1903, sacerdote ativo, zeloso, foi o décimo oitavo bispo do Maranhão 
era filho de Tomé de Alvarenga e de Josefina Maria das Dores de Alvarenga, revelou-se desde a infância que seria um pastor de almas na acepção da palavra, sendo ordenado por Dom Antônio, em Itu, a 25 de março de 1860, foi nomeado para servir nas paróquias de Taubaté, Casa Branca e Mogi das Cruzes onde elaborou os novos estatutos do Recolhimento de Santa Teresa (1877), era simpatizante ao abolicionismo, apoiando os empreendimentos em favor desse movimento. Indicado para atuar no Maranhão por Dom Pedro II, Imperador de Brasil, em 21 de setembro de 1877, aos quarenta e um anos, foi confirmado pelo Papa Pio IX no dia 31 de março de 1878, e sagrado por Dom Lino Deodato Rodrigues de Carvalho, estando a serviço da Igreja Católica do Maranhão por vinte anos, até que em 28 de novembro de 1898 foi indicado para a Sé de São Paulo, com a saúde debilitada, alguns anos depois veio a falecer.

O seu longo episcopado no Maranhão, assim como os anos transcorridos em São Paulo, se caracterizou por gestos de caridade e de zelo que honraria, dedicando-se ao melhoramento das condições religiosas, enfrentando corajosamente as dificuldades que lhe oferecia o espírito maçônico dominante àquela época e que segundo ele "se misturava a vida mundana sem o fermento íntimo e regenerador de uma fé viva e sincera".

Por outro lado, as dificuldades econômicas ocasionaram o fechamento do Seminário Menor, alojado no ex-Convento dos Mercedários em São Luís e o quase desaparecimento do Seminário Maior, tanto que tais problemas se aprofundavam com a escassez de clero, diante dos ataques dos adversários laicos e da generalizada ignorância religiosa dos fiéis. D. Antônio Cândido de Alvarenga compreendeu que só poderia remediar tal situação aguçada com o desaparecimento dos últimos mercedários, carmelitas e franciscanos, evento que contribuiu com a extinção no Maranhão destas três Ordens beneméritas, e o Governo apressara-se a confiscar os bens, talvez, o verdadeiro escopo visado pelo famoso Aviso Imperial de 1855, recorrendo ao auxílio dos adeptos da fé católica.

O zeloso bispo aproveitou-se então do fato dos capuchinhos lombardos, desembarcados em 1892 em Pernambuco, desejarem uma residência no Maranhão como "primeiro passo rumo ao último termo de sua missão, que era se dedicar à catequese dos índios nas margens do rio Amazonas”. Neste sentido, recebeu uma carta de Frei Carlos de S. Martino Olearo, a 18 de junho de 1893, dizendo-se satisfeitíssimo com o projeto 
"não só pela falta absoluta de missionários que há nesta Diocese para a evangelização dos índios e missões nas paróquias, mas também porque realmente sempre tive e tenho uma particular afeição à Ordem dos Capuchinhos".

Sugeria ainda Frei Carlos que, em virtude das dificuldades para a escolha de uma casa conveniente, viria pessoalmente a São Luís para averiguar as condições e, de comum acordo, acertarem as providências. Frei Carlos chegou a São Luís no dia 16 de agosto de 1893 e, facilmente, concordou com o Bispo sobre a necessidade de abrir uma missão na Diocese, desprovida de clero. Hospedou-se inicialmente no Seminário de Santo Antônio, depois aceitou a igreja de São João Batista, convertendo a casinha anexa num pequeno convento.

No dia 9 de novembro de 1893, entrava com seus companheiros nesta primeira residência e onze meses depois, isto é, aos 10 dias de outubro de 1894, com o apoio do Bispo e do Vigário-Geral Monsenhor Tolentino Morão, então deputado federal pelo Maranhão, se estabelecendo no velho convento das Carmelitas denominado Convento do Carmo, no centro de São Luís e que mais tarde seria comprado ao Governo pelos missionários. Entrementes, a Missão fundada por Frei Carlos, sob os auspícios de D. Antônio Cândido Alvarenga, a 12 de maio de 1894 alcançava o lugar canônico por decreto do Geral da Ordem e iniciava oficialmente a sua atividade apostólica.

Em 15 anos, a Missão fundou nove colégios (um em Barra do Corda, um em Alto Alegre, dois em Canindé, dois na Colônia de Santo Antônio de Prata, dois em Ourém, um em Manaus); destes colégios, seis destinavam-se a educação dos filhos dos índios, dando origem a dois grandes estabelecimentos coloniais (Alto Alegre e Santo Antônio de Prata) onde abriram quatro escolas de artes e ofícios (Barra do Corda, Canindé, Santo Antônio de Prata e Ourém) e pelo menos uma dezena de escolas primárias e gratuitas, entre as quais se destaca a de Fortaleza, dedicada a Pio X e que, no seu segundo ano de atividade, contava com a matricula de 814 alunos de ambos os sexos (1909); inaugurou duas tipografias (Canindé e Santo Antônio de Prata); dirigiu, além disso, um seminário menor diocesano em Canindé (Ceará), e o recrutamento de vocações nacionais à Ordem Capuchinha, destinadas mais tarde a se enquadrar numa regular sistematização, com o seminário seráfico, noviciado e estudantada filosófico e teológico. Por fim, construiu igrejas e conventos nos Estados do Ceará, Piauí, Maranhão e Pará. 
Sem dúvida, os resultados mais auspiciosos, foram colhidos por meio de milhares de missões pregadas ao povo, pelas inúmeras paróquias fundadas e nas intermináveis desobrigas através dos sertões, na catequese, nas capelanias de hospitais e leprosários; enfim, com o intenso movimento religioso iniciado nas igrejas por eles dirigidas, onde o número de santas comunhões distribuídas num ano atingiu a cifra de 250.000, como na Igreja do Sagrado Coração de Jesus em Fortaleza.

Dignas de notas são, ainda, as numerosas irmandades e associações religiosas fruto da pregação dos missionários como a difusão da Ordem Terceira Franciscana; a fundação de círculos operários católicos, como em Belém, Fortaleza, São Luís e Abaetetuba; a valiosa contribuição dos periódicos católicos impressos em suas escolas tipográficas; a obra de assistência prestada em tempo de epidemias contagiosas, de secas ou de pacificação durante movimentos revolucionários, como nas desordens promovidas pelos jagunços do Padre Cícero sob a orientação de Frei Davi de Dezenzano, Frei Mansueto de Peveranza, Frei Marcelino, de Cusano Milanino, Frei João Pedro de Sexto São João, Frei Inácio Tranquilino de Alzano e outros que conquistaram o coração de povo brasileiro, porque transcorreram a própria existência, sacrificando-se pelo povo sofrido dos sertões maranhense.

Como o objetivo de Frei Carlos de São Martino Olearo era a catequese dos índios, por ele idealizada não obstante as grandes dificuldades provenientes da escassez de meios e de pessoal, mas também preocupado pelas necessidades religiosas da região, cogitava se estabelecer em alguma paróquia do interior "para daí se irradiar em aldeias", seu plano era fixar pontos de onde pudesse irradiar a atividade dos missionários, e por isso, escreveu ao Provincial de Milão:

Revendo as minhas notas de viagem do ano passado, convenço-me de que o verdadeiro bem e a verdadeira civilização dos índios alcançarse-á exclusivamente mediante a nossa penetração no interior do Estado. A Missão do Mearim-Tocantins-Gurupi constituiria, por si só, um campo mais que suficiente. Uma casa em São Luís, com seis Padres que sirvam a cidade e deem missões ambulantes em todo o Estado; 3 Padres na Barra do Corda, paróquia maior que toda a Lombárdia, com 20.000 habitantes e 4.000 índios; 2 Padres em Pedreiras (meio caminho entre São Luís e Barra); em Vitoria; 2 em Grajaú; 2 em Turiaçu, 1 na Colônia Agrícola de Codó; e abrangeremos todos os índios de triangulo Grajaú-Tocantins-Mearim e prestaremos valioso auxílio à Dioceses do Maranhão, que se ressente de absoluta falta de clero. 
Por várias circunstâncias, este plano foi limitado e, depois, abandonado; a catequese dos índios foi, todavia, iniciada quer na Barra do Corda quer no Alto Alegre, pelos capuchinhos lombardos junto aos índios da Barra do Corda e Alto Alegre descrita por S. Exa. D. Helvécio Gomes de Oliveira:

Interrompida a catequese católica pela morte de Frei José de Loro, foi recomeçada pelos Capuchinhos Lombardos que, em 1895, se estabeleceram na Barra do Corda, fundando um internato para filhos de índios. Mais tarde, em 1896, fizeram um aldeamento de índios em "Alto Alegre", 12 léguas distante da Barra do Corda na estrada que vai desta cidade a Grajaú, e La foi criado um internato para as meninas índias, em 1899, sob a direção das Irmãs Terceiras Capuchinhas de Gênova.

Alto Alegre prestava-se para aldeamento e colégio, pois, estava situado entre as aldeias Guajajaras dos Canabrava, Crocagés, Côco e Genipapo. Para o serviço do aldeamento e colégio havia uma residência de religiosos (dois padres e um irmão leigo). No internado da Barra do Corda havia setenta e oito meninos índios, filhos de diversas tribos, as quais administrava, além do ensino de doutrina cristã e das letras, o das artes de alfaiate, sapateiro, ferreiro, carpinteiro e músico. O internato de Alto Alegre tinha quarenta e três alunos índios; tanta era a ordem e a aplicação deste internato que várias famílias abastadas de Barra do Corda e Grajaú empenharam-se para que recebessem ali as suas filhas. Este colégio funcionava em vasto edifico sobradado, contíguo à capela provisória.

Junto à residência dos padres havia um engenho para beneficiar arroz, mandioca, cana e algodão. As culturas se estendiam por mais de meia légua quadrada e tal o progresso de Alto Alegre e do colégio da Barra do Corda se julgou o Governo do Estado no dever de auxiliar a catequese, dando-lhe uma subvenção anual de doze contos de réis. No entanto, quis a história que na madrugada do dia 13 de março de 1901, índios de diversas tribos atacaram em Alto Alegre o colégio das Irmãs e a residência dos religiosos e dos civilizados matando-os tanto quanto aos habitantes dos arredores. Foram massacrados quatro frades, sete irmãs e cerca de duzentos cristãos laicos.

As causas presumíveis do massacre de Alto Alegre foram: 1) O ódio de homens ímpios que açulávamos índios contra os missionários; 2) A vida escandalosa destes mesmos cristãos, devassada na pregação evangélica; 3) O prejuízo pecuniário de pessoas que, ficaram privados de trabalhadores que, em Alto Alegre, recebiam justa remuneração do trabalho; 4) $\mathrm{O}$ temor de que os missionários viessem a ter 
preponderância em Barra do Corda e Grajaú; 5). A ignorância dos índios e o desejo de pilhagem da parte dos mesmos, excitados pela aguardente. Podendo ter como causa principal, segundo os religiosos, o ódio e a oposição contra o espírito cristão, tão bem pregado e melhor praticado pelos missionários.

Arrasado Alto Alegre, Barra do Corda continuaria a sua missão evangelizadora com a ajuda do governo, que segundo relatos de época por ser positivista, diretamente hostil a presença religiosa na região, mandou fechar o colégio e dispersar os alunos, liberando aos indígenas para voltarem aos seus aldeamentos ou que fossem adotados por outras paroquias ou famílias cristãs, dessa forma catorze menores foram levados para os colégios dos frades do Prata e Ourém (Pará) e outros vieram assentar praça no batalhão policial do Estado, onde se fizeram admirar pelos modos educados com que se apresentavam. O massacre do Alto Alegre e outras razões especificadas por D. Helvécio Gomes, infligiram duro golpe na Missão, mas não bastaram para detê-la em sua ação apostólica. A sólida instituição de Frei Carlos de S. Martino Olearo resistiu à tormenta e, embora constrangida, continuou sua dedicada influencia entre as populações por meio das missões, de desobrigas, dos apostolado paroquial, da assistência aos moribundos em época de epidemias contagiosas, de capelanias em casas religiosas e no leprosário, incentivando piedosas práticas e confrarias religiosas; e, enfim, com a ajuda do apostolado das irmãs terceiras capuchinhas realizados em colégios e escolas. D. Francisco de Paula e Silva, sem deixar de se referir às duras consequências do Alto Alegre, escreve nos Apontamentos de História Eclesiástica do Maranhão:

Fundou-se a Missão e teve o seu tempo de grande esplendor, contando 12 sacerdotes e 5 irmãos leigos, 6 irmãs e dois colégios (15). O morticínio do Alto Alegre abateu-se por muito tempo; ainda hoje sofre os efeitos dessa tremenda catástrofe. Mas os trabalhadores Capuchinhos estão estabelecidos e só Deus sabe o bem imenso que tem feito às almas desta Diocese. D. Alvarenga, que tanto trabalhou para esta fundação, deve ter uma longa parte nesses opulentos méritos.

O apostolado dos missionários fomentou amplo e constante programa de missões que se aplicaram também ao Maranhão que levou Luís de Câmara Cascudo (2000) escrever sobre as missões pregadas pelos capuchinhos no Nordeste brasileiro,

Construindo igrejas e cemitérios, riscando estradas, plantando cruzeiros, os capuchinhos ensinavam o catecismo, o simples, o lógico, o indispensável catecismo, divulgando orações singelas e cantos corais, de ampla e estupenda eficácia psicológica, tendo a intuição completados mistérios intelectuais do canto coletivo como liame de 
solidariedade moral. Os capuchinhos deram ao sertão os "benditos" cantados uníssono, por homens e mulheres, antes e depois das pregações. Essa tradição, que um temor idiota de parecer ridículo está fazendo desaparecer nas nossas igrejas, é uma das maiores dádivas. $\mathrm{O}$ homem sempre orou cantando, e cantando foram dirigidos os salmos, as suplicas e cantos de alegria onde mais alto subiu o coração humano de Davi e Salomão. Os capuchinhos faziam cantar. Ainda hoje os velhos sertanejos evocam o espetáculo indizível daquele coro de tragédia grega, informe e poderoso, bravio, rude, terrível, mas grandioso de eloquência, profundo de sinceridade, inesquecível de $\mathrm{Fe}$ intrépida. No pátio das pequeninas vilas sertanejas de cem anos, a multidão cumpria-se e daquele rebanho liberto do Mal pela palavra de fogo, subia aos céus estrelados e limpos o clamor da imensa voz ondulante e sonora, como hino de guerreiros que venceram, pelas armas da penitencia e da oração, o inimigo eterno do sossego e da paz nos espíritos...

Revivia-se na boca capuchinha a oratória dos santos e admiráveis tribunos, como as sandálias, a barba longa, a rústica indumentária, a coragem diária, o habito das missões sem conforto e sem fim, deram aos capuchinhos, em trezentos anos de campanha, a gloria dessa tradição automática e espontânea na memória e no coração do povo, conhecidos como os "santos missionários", por combaterem o pecado clamavam como haviam clamado Elias e Eliseu: "voz eterna que, mudando de timbre e de boca, mas não de intensidade e virtude, veio dos profetas hebreus aos catequizadores cristãos”. Frei Marcelino de Milão que em diferentes épocas pregou santas Missões também no Maranhão, nos anos de 1915, 1918, 1922, descreve pormenorizadamente a procissão final de penitencia com que geralmente se encerram as missões.

Impossível olvidar uma das características mais tocantes das missões, isto é a procissão penitencial. Quando o sol vai-se pondo no horizonte, acendem-se as velas e milhares de luzes tremulantes descrevem, já por entre as trevas que descem, duas résteas luminosas, intermináveis. Da cruz, que guia o imenso cortejo, aos sacerdotes missionários, que o encerram, erguem-se vozes de todos os timbres, das brancas e argentinas das crianças e das jovenzinhas às de tenor, de barítonos e másculas dos homens. São notas plangentes que sobem ao céu, motivos cheios de tristeza e dor que se entrelaçam, se unem para explodir em gemidos e suplicas; são cantos populares que traduzem a contrição do coração, propósito firme, resolução irrevogável; são vozes comovidas que entoam louvores a Virgem, explosões jubilosas de espíritos regenerados, em que vibra a nota do amor e da gratidão a Deus, enchendo a amplidão dos céus. Não há olhos que se não encham de lagrimas ao contemplar este espetáculo, não há coração empedernidos que seja na culpa, que se não sinta comovido e chore. É a noite da pesca milagrosa, a hora dos santos propósitos, os momentos das vitórias da graça divina. 
Com relação à deficiência de clero, as condições da Diocese de São Luís foram se agravando com os sucessores de D. Antônio Cândido de Alvarenga, como seguramente é visto em documentos com depoimentos de missionários e visitadores da Missão. Frei Hilarião de Lodi escrevia ao Geral da Ordem a 24 de fevereiro de 1902:

Estou visitando com o Bispo de S. Luís as paróquias do Maranhão e Piauí; é angustioso ver tantas igrejas sem pastor. Vários sacerdotes devem cuidar de duas ou três paróquias (como se uma só não bastasse) que se estendem por 15 ou 20 mil km², além das enormes dificuldades de comunicação. Faltam padres e os fiéis permanecem abandonados. O Bispo preocupa-se muito com esta escassez de clero.

Em 1905, era criada a nova Diocese do Piauí, desligada da jurisdição espiritual de São Luís, mas o problema de falta de clero em vez de se atenuar, parecia aumentar com o correr dos anos. O provincial dos capuchinhos de Milão, Frei Camilo de Albino, que em 1909/1910 visitava a Missão, escrevia em seu relatório final:

Não receio afirmar que a Diocese mais necessitada de operários evangélicos, em todo o Norte do Brasil, é o Maranhão. É a mais extensa dentre as Dioceses circunvizinhas e conta com 750.000 habitantes e o clero é escassíssimo. O Bispo atual, D. Francisco de Paulo e Silva, lazarista, verdadeira pérola do Episcopado, diziam-me suspirando: "Sou um capitão sem soldados: em toda a Diocese não tenho mais que vinte padres...: que posso eu fazer nestas condições? Pelo amor de Deus, aumente o número de missionários, mormente na Barra do Corda.

Por outro lado, o problema se agrava considerando-se que o protestantismo estava se espalhando junto à população maranhense e radicando-se em São Luís, Pinheiro, Pedreiras, Barra do Corda, Caxias, Carolina, Grajau e outras zonas; e em muitos povoados grandes e pequenos, abriam-se tendas espíritas que se aproveitando da ignorância e do abandono em que se acham os fiéis, os recebiam de braços abertos.

Cônscios da situação, os missionários convergem seus esforços para vir em auxilio do clero e atender as ingentes necessidades espirituais dos católicos. Encarregam-se então do paroquiado e tem início o "incessante viajar" das desobrigas através do sertão, torturados pelo sol abrasador e pela sede, mortos de sono e de cansaço. Em 1906 as paróquias confiadas à residência de São Luís, são sete, e quatro as paróquias dos religiosos da Barra do Corda, sem contar as capelas na Capital e a suplência provisória em outras freguesias. Em 1911 o número de paróquias organizadas pelos frades eleva-se a treze, atingindo mais tarde, dezessete. Com grande entusiasmo os missionários investem nas viagens, por meses de "vida errante" na solidão das 
florestas, expostos a toda espécie de perigos, num clima adverso e, amiúde, curtindo forme e sede, Frei Querubim de Carpiano assim concluía a sua Relação, datada de janeiro de 1903:

Agradeço à Providencia divina haver-me dado a graça especialíssima da vocação missionária. É uma vida de sacrifício, não há dúvida, mas que importa? Vivida pelo amor de Deus, produz grande consolação... A vida de desobriga agrada-me mais do que qualquer outra porque dá possibilidade de fazer um bem imenso e sem ninguém o aperceba. É realmente uma vida apostólica: as canseiras das viagens a cavalo, a fome, a sede, as febres palustres, tudo isto constitui o segredo da redenção das almas.

De resto, expressões semelhantes encontram-se também nas relações dos outros missionários, como Frei Josué de Monza, Frei Cirilo de Bérgamo, Frei Germano de Cedrate, Frei Roberto de Castellanza, Frei Miguel de Origgio. Enquanto paroquiava a vila de Rosário, Frei Josué de Monza, é acometido de malária tão intensa que o Superior lhe manda um irmão leigo para o trazer ao convento. Escreve ele em seu relatório: "Que estas pequenas provações sirvam para a salvação de almas”. Ao voltar da desobriga, após 8 meses de fadigas e viagens esfalfantes, Frei Miguel de Origgio declara-se alegre de que Deus tenha servido do seu sacrificio para "abundar nos corações". Em 1906, acenando a um ciclo de missões pregadas com Frei Abraão de Rescalda, escreve Frei Germano:

O sol tropical, a poeira, o enfado das viagens a cavalo e o trabalho ingente não eram a nossa morte, mas a nossa consolação, a nossa vida. Conquanto nos multiplicássemos, em nenhum lugar nos foi possível atender a todos os fiéis que acorriam às santas Missões. Trabalhava-se de 4 horas da madrugada até depois da meia-noite, as mais das vezes; e sempre ficavam pessoas sem poder se confessar, com grande tristeza nossa e deles.

O trabalho dos missionários no Maranhão, exercido sob as mais variadas formas de apostolado, continuou nos anos seguintes, sem descanso e sem conforto. O número das paróquias assistidas diminuía ou aumentava conforme as circunstâncias; em média, chega a uma dúzia, de preferência no interior do Estado, onde, sucessivamente, entravam na órbita da residência da Barra do Corda; a paróquia de Grajaú, de Imperatriz, de Loreto, de Riachão, ade São Luís Gonzaga, de Pedreiras, de Santo Antônio de Balsas à margem do afluente do rio Parnaíba, e até a remotíssima freguesia de Vitória do Alto Parnaíba nos confins do Maranhão com o Piauí. 
Em 1910, Barra do Corda é enriquecida de um colégio dirigido pelas irmãs terceiras capuchinhas; no mesmo ano o dinâmico superior Frei Lourenço de Alcântara, a fim de combater o protestantismo, institui a Conferência de São Vicente e organiza aguerridos grupos de marianos. Aliás, como já salientamos quando falamos nas Missões de todo o Norte do Brasil, também no Maranhão associações e confrarias religiosas, centros de catecismo, obras de assistência social, humanitária e cultural são criadas pelos missionários, onde quer que lhes seja possível porque da atividade fundamental brotem as iniciativas marginais que a completam e vivificam.

Para limitarmo-nos ao extremo sul do Maranhão e à atividade apostólica que gravita nas imediações de Barra do Corda, entendemos que o problema mais grave ali, era o representado pelas distâncias. Os missionários residentes na Barra deviam percorrer centenas de quilômetros a cavalo, antes de alcançar o próprio campo de trabalho, daí o desperdício de energias e de tempo e com o passar dos anos a situação se torna insustentável, não são poucos os missionários que, no fim de suas excursões anuais tenham percorrido 3.500 até 4.000 quilômetros, a cavalo, tanto que em fevereiro de 1915 Frei Josué de Monza, superior da Barra do Corda, escrevia: "O nosso trabalho aqui compreende seis paróquias vastíssimas, com a superfície de $150.000 \mathrm{~km}^{2}$ mais ou menos, de forma somente podemos visitá-las uma vez por ano. Os três padres: Querubim, Natal e Lourenço, animados de santo entusiasmo e cheios de boa vontade, desobrigam de abril até dezembro, matando-se de trabalho". Ouçamos também um dos três supramencionados, Frei Natal de Besana:

Com exceção dos dois primeiros meses, passei o ano todo desobrigando e missionando com o meu ótimo e inteligentíssimo Frei Marcelino de Milão. Entre desobrigas e missões percorri $3.420 \mathrm{~km}$, sempre a cavalo, sob os raios de um sol abrasador. Duas vezes adoeci. Desobrigamos e pregamos missões me Grajaú, Imperatriz, Riachão, Santo Antônio do Balsas, Barra do Corda e Pedreiras".

Às vezes, os missionários demoram-se meses a fio nos lugares onde é necessária a sua presença para consertar ou renovar igrejas, como está acontecendo com Frei Germano em Pedreiras, onde está construindo a igreja; mas a desobriga reclama-o e, atrasando-se por causa deste trabalho deverá deliciar-se, com uma cavalgada de 2.400 km., feita às pressas, com as respectivas paradas para instruções, confissões, comunhões, casamentos e tudo o mais que a desobriga comporta, assim concluindo: 
“dois fatores principais concorrem para abreviar a vida dos pobres missionários nesta região: o clima tropical e o trabalho sem tréguas".

Restava ainda o problema dos indígenas, impossível de solucionar não só radicalmente, mas, em tais condições, nem sequer satisfatoriamente. A residência da Barra do Corda continuava a ser visitada pelos aborígenes e os missionários ocupados com as desobrigas, visitavam vez por outras suas aldeias, não deixando de instruí-los e celebrar "todas as práticas religiosas ao alcance deles". Todos, porém, reconheciam que isto era tão somente uma remediação e não a solução do problema. Todas estas razões foram criando um novo clima na Missão e determinaram a convergência das opiniões para a escolha de um campo de ação, limitado e definido, que devia possivelmente concentrar-se numa Prefeitura Apostólica ou numa Prelazia "nullius"; naturalmente isso provocaria um novo afluxo de missionários, multiplicando residências e oferecendo a probabilidade de melhor organização.

Quem primeiro apresentou á ideia da entidade eclesiástica independente no interior do Maranhão, abrangendo as paróquias já assumidas pelos missionários da Barra do Corda, foi Visitador Geral da Missão Frei Camilo de Albino. Esta ideia nasceu em Frei Camilo por duas considerações: 1) as grandes necessidades espirituais da Diocese de São Luís, atendendo-se para o reduzido número de sacerdotes diocesanos; 2) o trabalho excessivo que recaia sobre os missionários da Barra do Corda, obrigados a permanecer oito ou dez meses, num ano, fora de suas residências. Com a criação de uma Missão independente, ele prometia dividir o imenso território da Diocese de São Luís, facilitando, assim, ao clero a indispensável assistência aos fiéis; multiplicadas a par, as residências missionárias, o trabalho tornar-se-ia mais proveitoso e humanamente tolerável.

Esta tentativa, que data de 1910, falhou por vários motivos apresentados quer pelo Bispo de São Luís, quer pelos mesmos missionários. O Bispo manifestou o receio de que a Diocese pudesse ficar prejudicada, cedendo "parte tão avultada do seu território", o que iria acabar desgostando o clero e os fiéis; os missionários, favoráveis ao projeto, não esconderam suas preocupações quando souberam que a realização deste plano incluía o abandono das residências já abertas e sustentadas com tantos sacrifícios no Pará, para ficar com pessoal disponível, visto como da Província monástica não podiam vir outros missionários. 
O projeto de uma prelazia independente reapareceu em 1915 por iniciativa do novo Visitador Geral Frei Jerônimo de Lomazzo. Também nesta circunstância sobressai a vontade firme da Província Lombarda de querer limitar o vastíssimo campo da Missão, que se estendia do Ceará ao Pará, visando com isto maior concentração de missionários no Maranhão, grandemente necessitado de clero. Desta vez, vendo a firme resolução da Província, os missionários mostraram-se dispostos a retirar-se do Pará ou do Ceará; por isto, a 7 de março de 1915, o Visitador Geral escrevia de Belém do Pará ao Bispo de São Luís para entabular as práticas necessárias.

A resposta do Exmo. Sr. Bispo, de 20 de março do mesmo ano, ventila o assunto já tratado na carta anterior consignada a Frei Camilo de Albino, isto é; pessoalmente o Ordinário é favorável à criação da projetada circunscrição eclesiástica; surgem, entanto, graves dificuldades relativamente ao seu múnus episcopal, pelo que não se sente de assumir diretamente a responsabilidade de apresentar o projeto a Santa Sé. Na realidade, admitindo-se a vontade dos homens, fazia-se necessário elementos novos para sair do ponto morto, o que não verificaria senão mais tarde se concretizando na relação de 1918, quando o Superior Regular da Missão Frei Roberto de Castellanza volta a abordar o argumento e escreve:

Os missionários da Barra do Corda passam quase todo o ano desabrigando as paróquias da Barra, Grajáu, Imperatriz, Riachão, Loreto e São Luís Gonzaga; as distâncias entre as paróquias é de 300 $\mathrm{km}$ para mais, ficando na residência somente o Superior e o irmão leigo. Eu que conheço estes lugares, posso avaliar as penúrias e os sacrifícios suportados por estes nossos valorosos companheiros, pela salvação das almas. Ah! É preciso dizer que, embora no passado não se julgasse talvez oportuno, o mais certo fora erigir uma Prelazia ou Prefeitura; assim a Missão poderia abrir, mas algumas residências neste imenso sertão, com grande processo espiritual para os mesmos missionários que, pela grande distância entre as paróquias e por se encontrarem muito longe uns dos outros, durante a desobriga passam meses a fio sem se confessar! Demais, isto seria de grande vantagem para estes fiéis, quase abandonados, porque só veem o padre uma vez por ano e, às vezes, nenhuma. Deste modo, a maior parte do povo permanece sem sacramentos, sendo impossível ao missionário visitar todos os lugares e desobrigar todas as casas.

A criação duma prelazia "nullius" foi determinada por várias circunstâncias preparadas de 1920 a 1921. Com a morte de D. Francisco de Paula e Silva em 1918, subia à sede episcopal de São Luís, D. Helvécio Gomes de Oliveira, homem de grande visão e sincero admirador da obra dos capuchinhos, tomou logo a peito as prementes necessidades da Diocese não só com relação aos fiéis, mas também dos pobres nômades 
das selvas, os índigenas, espalhados pelas margens dos rios Mearim, Grajaú, Pindaré e Gurupi. Tendo a Nunciatura Apostólica do Rio solicitado, confirmando que, não dispondo de clero e de recursos, a Diocese, em ampla relação o Sr. Bispo resumia os principais dados históricos, confirmando que, não dispondo de clero e de recursos, a Diocese de São Luís não podia enfrentar semelhante tarefa.

Acrescentava, porém, que, se os capuchinhos lombardos com ordens da Santa Sé aceitassem a catequese dos índios, de boa vontade cederia "algumas paróquias do interior, constituídas ou não em forma de Prefeitura Apostólica ou mesmo de Prelazia" que servissem de base para a projetada catequese. Com isso, dava-se o primeiro passo rumo à constituição da nova prelazia e outro passo ocorreu nos primeiros meses de 1921, quando o Governo do Pará resolveu fechar a Colônia de Santo Antônio do Prata. A partir de 1898, os capuchinhos lombardos, tinham transformado uma légua de mata virgem, em fertilíssima colônia para a civilização dos índios, dotando-a de dois colégios para meninos e meninas indígenas, de igrejas, de escolas e de numerosas casas para os cristãos e para os índios civilizados, oferecendo a Colônia aspecto risonho de pequena cidade entre o verde perene da mataria circunstante.

Com o tempo surgiu, a uns quilômetros do centro, um arraial com outra igrejinha dedicada a Santo Isidoro, padroeiro dos lavradores, e em direção oposta construiu-se uma nova capela dedicada a São Francisco de Assis. A realização destas obras só foi possível mediante a mais escrupulosa economia das subvenções do Governo, muitas vezes obtidas com a maior dificuldade por causa das frequentes crises econômico-financeiras em que se debatia o Pará e, também, pela inconstância da política que mudava de rumo de um Governador para outro.

\section{A FUNDAÇÃO DA PRELAZIA DE SÃO JOSÉ DE GRAJAÚ}

Como remate das continuas indecisões que caracterizaram o passado político do Maranhão, em fins de 1920 o governo do Pará subitamente decidiu fechar a colônia, obrigando os frades a se retirarem e condenando à morte certa tudo o que se havia realizado, inclusive os colégios e as áreas cultivadas. Isto sucedia nos meses de março e abril de 1921. Este fato, vinha, todavia, coloca à disposição do Superior da Missão alguns religiosos e algumas freiras capuchinhas para a prelazia maranhense, há longos anos projetada. Sem perda de tempo, Frei Roberto de Castellanza dirigiu-se a D. Helvécio Gomes ressaltando a possibilidade de se concretizar tudo o que o Bispo já 
havia manifestado na carta à Nunciatura Apostólica acerca das paróquias do interior do Maranhão, como base para a catequese dos índios. Escrevia Frei Roberto:

Nesse transe angustioso consola-me a proposta V. Exa. Revma. De oferecer-nos, de acordo com a Santa Sé, algumas freguesias da vastíssima Diocese do Maranhão, embora longínquas, às quais, há bem quatro lustros, já éramos incumbidos de administrar panem vitae aeternae: de ceder-nos a zona habitada pelos índios. Nesse capo evangélico, servatis servandis, esperamos, aproveitando dos Padres recém-chegados da Itália e dos Missionários que serviram no Prata, abrir e estender novas tendas do nosso apostolado, intuito primitivo da nossa vinda ao Norte do Brasil, e formar focos de piedade nos pontos principais mais povoados e algum centro de catequese de índios Gurupi. Estou certo que toda a Missão ficará satisfeita; os nossos Superiores Maiores, de Milão e de Roma, de boa vontade nos darão a devida licença e o nome de V. Exia. Revma. ficará sempre gravado no coração dos pobres filhos do Serafim de Assim.

Assim, o problema da Prelazia encontrava circunstâncias tão favoráveis, caminhando a passos largos para a sua solução natural e exatamente dois meses depois desta última carta de Frei Roberto após entendimentos com a Nunciatura Apostólica, D. Helvécio Gomes concretizava seu pensamento expresso na carta de 12 de fevereiro de 1921 e apresentava à Santa Sé o pedido formal para a constituição de uma prelazia "nullius" no interior do Maranhão, com sede em Grajaú e sob a proteção de S. José, esposo da Virgem Mãe de Deus e Patrono da Igreja Universal.

A carta de D. Helvécio Gomes ao Núncio Apostólico, acerca da criação da Prelazia de Grajaú, é do dia 9 de junho de 1921 e como é praxe da Santa Sé, a propostapedido do Exmo. Ordinário de São Luís foi minuciosamente estudada e, visto que o Arcebispado de Belém tinha apresentado petição naquela mesma época à Santa Sé para que a Diocese de São Luís fosse elevada ao grau de Arquidiocese, no dia 2 de dezembro de 1921 S. S. o Papa Bento XV dignava-se aprovar conjuntamente os dois projetos. Nesta data, porém, a bula não estava ainda pronta e diante da morte do grande Pontífice Bento XV em 1922 coube ao Papa Pio XI publicar a 10 de fevereiro de 1922, a bula Rationi Congruit que elevava a Diocese de São Luís a Arquidiocese e sede de Província Eclesiástica e, ao mesmo tempo, criava a Prelazia de São José de Grajaú, com a superfície de mais de um terço do Maranhão e uma população de quase 103.000 habitantes, compreendia as cinco imensas paróquias sertanejas já indicadas por D. Helvécio Gomes, isto é, Santa Cruz da Barra do Corda, Nosso Senhor do Bonfim de Grajaú, S. Pedro de Alcântara de Carolina, Santa Teresa de Imperatriz e Porto Franco, e 
S. Francisco Xavier de Turiaçu. A Bula Pontifícia foi executada no começo de julho de 1922 e, pouco depois, a Província Capuchinha de Milão comunicava formalmente que aceitava a Prelazia, apresentando ao mesmo tempo o seu candidato para Administrador Apostólico na pessoa de Frei Roberto de Castellanza que, há quase 24 anos, trabalhava como missionário no Brasil, e que, há 4 anos, vinha governando toda a vasta Missão como Superior Regular.

Terminadas todas as formalidades e finalmente levados a bom termo os trabalhosos relativos a implantação e a efetivação da Prelazia, o ultimo gesto da Ordem Capuchinha foi um caloroso agradecimento àquele que tinha sido o principal artífice da nova entidade eclesiástica, a saber, D. Helvécio Gomes de Oliveira. No dia 17 de julho de 1922, o Geral da Ordem Revmo. Frei José Antônio de Persiceto escrevia,

\begin{abstract}
"Exa. Revma., foi com a maior satisfação que recebi a Sagrada Congregação Consistorial a proposta da aceitação da Prelazia "Nullius" de S. José e envidei todos os esforços para levar a termo, no menor espaço de tempo, todas as relativas práticas. Graças a Deus, a empresa pode-se considerar ultimada, e confio sinceramente que a pessoa apresentada pelos Superiores como Administrador Apostólico desempenhará dignamente o honorífico e delicado encargo. Entrementes, a Ordem Capuchinha contraiu uma nova dívida de gratidão para com V. Excia. Revma. pelo gesto deveras honroso com que V. Revma. se dignou prestigia-la; e eu, como Supremo Superior da mesma Ordem, sinto-me no dever de lhe apresentar os meus vivíssimos agradecimentos e a expressão da minha profunda gratidão, interpretando, deste modo, os sentimentos dos meus religiosos e particularmente dos capuchinhos lombardos que veem aumentar as suas dívidas de gratidão para com V. Exa. Revma.
\end{abstract}

A Prelazia de Grajaú foi desmembrada da Arquidiocese de São Luís do Maranhão em 10 de fevereiro de 1922 através da bula Rationi Congruit, do Papa Pio XI, sendo confiada aos Frades Menores Capuchinhos italianos. A sede da diocese era onde hoje fica o monumento em honra a Frei Alberto Beretta, na década de 1940, foi construído um templo juntamente com a cúria, obra do frade italiano Frei Francisco de Chiaravalle, no período de episcopado de D. Júlio Roberto Colombo. Em 4 de agosto de 1981, através da Bula Castellum Tratoports do Papa João Paulo II, foi elevada a diocese. A 9 de outubro de 1984, por decreto da Congregação para os bispos, passou a ser chamada de Diocese de Grajaú. 


\section{REFERÊNCIAS}

\section{FONTES PRIMÁRIAS}

ARQUIVO DA ARQUIDIOCESE DE S. LUÍS (S. Luís, Paço Episcopal). Interessa documentos relativos à constituição da Prelazia de Grajaú e, anteriormente, à evolução histórica da Diocese de S. Luís e da "Missão do Maranhão" (1893 - 1922). Deve-se, porém, notar que, documentos referentes à obra dos capuchinhos, existe geralmente cópias conservadas nos arquivos da Ordem.

\section{ARQUIVO DA CUSTÓdIA PROVINCIAL, CAPUCHINHA DO MARANHÃO} (S. Luís, Convento do Carmo). É o arquivo oficial da chamada "Missão do Maranhão" fundada em 1893 por Frei Carlos de S. Martino Olearo e transformada em Custódia Provincial do Maranhão em 1937. Dividido por 32 gavetas (gav.) marcadas com algarismos arábicos, contém cartas, relatório, estatísticas, mapas, correspondência com os superiores da Ordem, bispos e governos estaduais e outros documentos concernentes ao estudo. Por sua vez, cada gaveta contém várias coleções (Cartas) distintas por letras maiúsculas do alfabeto.

\section{ARQUIVO GERAL DAS MISSÕES CAPUCHINHAS}

Este arquivo, sob a indicação: H 47 (Praelatura Sancti Jsephi de Grajaú) e H 67 (Missio Maragnani in Brasília) contém milhares de documentos referentes à Prelazia de Grajaú e inclui os "Documenta Officialia" (Doc. Off) e as "Relationes particulares" (Rel. par.) de missionários. Atendendo-se ao critério das Missões, fundações de residências, colégios, escolas, desenvolvimentos da ação missionária, transferências de pessoal, etc., deviam ser tratadas com o Geral da Ordem; além disso o Statutum impunha tanto aos superiores como aos súditos enviassem anualmente um relatório da própria atividade missionária.

ARQUIVO DA PRELAZIA DE GRAJAÚ (Grajaú, Paço Episcopal).

Trata-se do arquivo que, naturalmente, serve de base para o presente estudo. Os documentos estão ordenados conforme cada matéria ou argumento, e guardadas em gavetas (Gav.) marcadas com algarismos arábicos. Por sua vez, cada gaveta contém várias coleções (Cartas), assinaladas com letras maiúsculas do alfabeto. O material contido neste arquivo tem, certamente, maior ou menor importância, mas não há prescindir dele, para um estudo sobre a Prezalia. Entre as coleções de maior valor salientamos a 13/B, que contém a correspondência entre o superior eclesiástico e a Nunciatura Apostólica do Rio; a 11/C o Livro de Tombo da Prelazia encerra numerosos documentos oficiais; a 13/A, com informes sobre a fundação e evolução de cada paróquia; e a 14/A, que compreende as relações oficiais remetidas à Santa Sé, ao Núncio e aos superiores da Ordem.

\section{LIVROS DE TOMBO}

LIVRO DE TOMBO DA FREGUESIA DA BARRA DO CORDA (Barra do Corda , Arquivo Paroquial),1895. São três volumes manuscritos em que se anota, ano por ano, todo o movimento religioso da paróquia, dedicada à Santa Cruz, tanto na sede como no sertão, mediante a periódica desobriga.

LIVRO DE TOMBO DA FREGUESIA DE IMPERATRIZ (Imperatriz, Arquivo Paroquial de Imperatriz, consta de dois volumes manuscritos; o primeiro abrange o 
período de 1922 a 1937; o segundo vai de 1938 até1949. Trata-se, globalmente, de uma centena de folhas com notas e apontamentos redigidos pelos vários superiores da residência.

\section{FONTES SECUNDÁRIAS}

AMORIM, Maria Adelina. História dos Franciscanos no Maranhão e Grão-Pará: missão e cultura na primeira metade dos seiscentos. Universidade Católica Portuguesa, Lisboa, 2005.

CASCUDO, Luís da Câmara. História, escola da compreensão. A República, Natal, 08 jul. 2000.

CONDURU, Felipe. História Eclesiástica do Maranhão. Departamento de Cultura do Maranhão, São Luís-MA, 1969.

MEIRELES, Mario Martins. História da Arquidiocese de São Luís do Maranhão: no tricentenário de criação da diocese. Gráfica da Universidade do Maranhão, 1997.

NERIS, Weriston Silva. A elite eclesiástica no bispado do Maranhão. Paço Editorial. São Paulo 2014.

SILVA, Francisco de Paula e. Apontamentos para a História Eclesiástica do Maranhão. Departamento de Cultura do Maranhão, São Luís-MA, 1969.

\section{Recebido em: 01/02/2022}

Aprovado em: 01/03/2022 